\title{
COMPARISON OF ONLINE VS CLASSROOM DELIVERY OF UNDERGRADUATE BASIC MEDICAL SCIENCES MODULE
}

\author{
Fouzia Hanif a , Fatima Ehsan ${ }^{\mathrm{b}}$, Nasim Ilyas ${ }^{ }$, Safia S.Khan ${ }^{\mathrm{d}}$ \\ ${ }^{a}$ Assistant Professor, Department of Biochemistry, Federal Medical and Dental College. \\ ${ }^{b}$ Associate Professor, Physiology Islamic International Medical College, Rawalpindi/Riphah International \\ University. \\ ${ }^{c}$ Associate Professor Department of Biochemistry Poonch Medical College, Azad Jammu Kashmir. \\ ${ }^{d}$ Assistant Professor, Department of family \& Community Medicine, Neurology \& Neurotherapeutics \\ University of Texas Southwestern Medical Center Dallas, USA.
}

\section{ABSTRACT:}

BACKGROUND \& OBJECTIVE: Corona virus disease (COVID-19) has impacted lives globally with serious consequences. Universities are facing immense challenges in transition to online education. The objective was to evaluate the effectiveness of online system of teaching in COVID-19 as compared to classroom teaching in a basic medical sciences module.

METHODOLOGY: This is a cross-sectional study, conducted at Islamic International Dental College, from $15^{\text {th }}$ February to $15^{\text {th }}$ May 2020 on $1^{\text {sT }}$ year BDS students. At the end of their online module, an online feedback questionnaire was given to students. Assessment of the online module was compared with the previous class module assessment, to get an insight of their performance. SPSS version 25 was used for data analysis.

RESULTS: A highly significant $p$ value was found in both Physiology and Biochemistry online tests as compared to class tests. Regarding feedback, 63(91.3\%) students preferred classroom teaching as it enhanced active participation $59(85.5 \%)$ and student teacher engagement $62(89.9 \%)$. Students agreed that queries were addressed during online sessions 57 (70.9\%) but they seemed less motivated $21(30.4 \%)$ and grasping of difficult concepts was tough $48(69.5 \%)$. Teachers seemed to be more enthusiastic in online teaching $52(75.4 \%)$, but there were variety of teaching tools used in classroom sessions 65 (94.2\%).

CONCLUSION: Gradually medical universities, faculty and students will adapt to e-learning, our results showed students even underperforming students picked up e-learning effectively. However more innovative and proactive measures for students and faculty to enhance students learning.

KEY WORDS: COVID-19, Pandemic, Online teaching, Classroom teaching, Effectiveness.

How to cite this:

doi: https://doi.org/10.37723/jumdc.v11i4.479

Hanif $F$, Ehsan $F$, Ilyas $N$, Khan SS. COMPARISON OF ONLINE VS CLASSROOM DELIVERY OF UNDERGRADUATE BASIC MEDICAL SCIENCES MODULE. jumdc. 2020;11(4):40-46.

doi: https://doi.org/10.37723/jumdc.v11i4.479

This is an Open Access article distributed under the terms of the Creative Commons Attribution License (http://creativecommons.org/licenses/by/4.0), which permits unrestricted use, distribution, and reproduction in any medium, provided the original work is properly cited. 


\section{INTRODUCTION:}

Since ancient times the classroom has been the standard venue for teaching \& information delivery to students. However, online courses have also been offered in higher education in general according to specific curriculum for many years. From the healthcare and medicine perspective, various short online courses have been running successfully globally ${ }^{[1]}$.

During this COVID-19 pandemic crisis and the startling growth of cases, deaths and distribution, a lot has been going on globally in terms of quarantine, travel bans, online classes, work from home and lockdowns ${ }^{[2]}$. It is of utmost importance that the education cycle should not be disrupted and genuine efforts are made to switch over to online education.

Online courses have both advantages and disadvantages in classroom setting. Many factors can influence whether or not an online learning program will succeed or fail, ranging from student led factors to staff led factors. Online courses are flexible both in terms of timings and where students learn material and the pace at which they learn course material ${ }^{[3-4]}$. With online courses students need to be more actively involved in learning course material, which as a positive aspect lead them towards self-regulated learning. Online teaching system is not part of routine academics; thus, some students experience more anxiety and may spend more time on online courses than on face-to-face learning ${ }^{[5]}$. However experiences with hybrid teaching involving both face to face as well as e-learning has shown beneficial results most of the time getting students exposed to a variety of teaching modalities ${ }^{[6]}$.

Pakistan is a country with low budget allocation to health and education; therefore, utilization of funds in medical schools should aim for improvement. There is an initial cost for the software system with technical expertise to create private websites with online courses for educators / faculty of an institute. An active internet connection is must for its successful delivery, which if not working properly especially in remote places can cause frustration for students and additional work for universities ${ }^{[7]}$. Similarly, lack of individual space at homes in joint family systems and nondisciplined lifestyle with lack of focus during e-
Corresponding Author:

Dr. Nasim Ilyas

Associate Professor Department of Biochemistry Poonch Medical College, Azad Jammu Kashmir.

'Email: biochemistry.iimct@gmail.com

learning are big challenges for students ${ }^{\left[{ }^{8]}\right.}$. The faculty is not properly trained for online classes as you need to find ways to ensure participation of students, and the quality and quantity of interaction has to be increased to attain the learning goals. There is no awareness about digital learning ethics which has worsened the situation ${ }^{[9]}$.

Thus, present study was undertaken in the wake of COVID-19 when it has become inevitable for all universities to transit towards the e-learning and see its impact in an undergraduate medical module to better prepare for the encountering challenges in online learning.

\section{METHODOLOGY:}

A descriptive cross-sectional study, was done in Islamic international Dental College, Islamabad, from $15^{\text {th }}$ February to $15^{\text {th }}$ May 2020. Block sampling method was used and every $2^{\text {nd }}$ student of current and old $1^{\text {st }}$ year BDS class was selected. In this way sample size was calculated to be 75 . Only those medical students were selected which have undergone training through both types of teaching methodologies. Migratory students were not included in this study. It was questionnaire-based study and questionnaires were disseminated online. ${ }^{[21]} \mathrm{MS}$ Excel and SPSS 25 were used for analysis of data. Quantitative data was interpreted using independent sample $t$ test, whereas for qualitative analysis Chi square test was used. Informed consent was obtained from all respondents and study was approved by institutional ethical committee.

\section{RESULTS:}

The class of $1^{\text {ST }}$ year BDS in 2020 consisted of 75 students, among whom 69 (i.e. 92\%) participated in the study.

Test marks data analysis in Table-I showed that in Biochemistry, Classroom teaching had a 
Mean \pm S.D as $9.4627 \pm 4.07627$ while the online teaching had $11.2571 \pm 3.82473$ with a $\mathrm{p}<0.05$ which was significant. Similarly, in Physiology, Classroom teaching had a Mean \pm S.D as 20.1940 \pm 6.93310 while the online teaching had $25.9810 \pm 7.63328$ with a $\mathrm{p}<0.05$ which was again significant.
Qualitative data analysis showed that majority of students, $63(91.3 \%)$ preferred classroom teaching as it enhanced active participation 59 $(85.5 \%)$ and student teacher engagement 62 $(89.9 \%)$. Although students agreed that their queries were immediately addressed during online sessions 57 (70.9\%) but they seemed

Table-I: Comparison of test marks between Classroom \& online teaching.

\begin{tabular}{|c|c|c|c|}
\hline Assessment & Teaching Mode & $\begin{array}{c}\text { Test Marks } \\
\text { (Mean } \pm \text { S.D) }\end{array}$ & $\begin{array}{c}\text { Significance } \\
\text { (p-value) }\end{array}$ \\
\hline \multirow{2}{*}{ Biochemistry } & Classroom & $9.4627 \pm 4.07627$ & $<0.05$ \\
\cline { 2 - 3 } & Online & $11.2571 \pm 3.82473$ & \\
\hline \multirow{2}{*}{ Physiology } & Classroom & $20.1940 \pm 6.93310$ & \multirow{2}{*}{$<0.05$} \\
\cline { 2 - 3 } & Online & $25.9810 \pm 7.63328$ & $<$ \\
\hline
\end{tabular}

Data was divided in two groups High and Low achievers (combining both Biochemistry and Physiology tests), those scores above the median score were categories as high achievers (Has), whereas those scoring below the median were classified as low achievers (LAs)'. A highly significant $p$ value $(P<0.001)$ was indicative that online assessment markedly enhanced students' performance among LAs $(19.56 \pm 7.56)$ compared to HAs $(9.09 \pm 2.92)$ as shown in (figure-I).

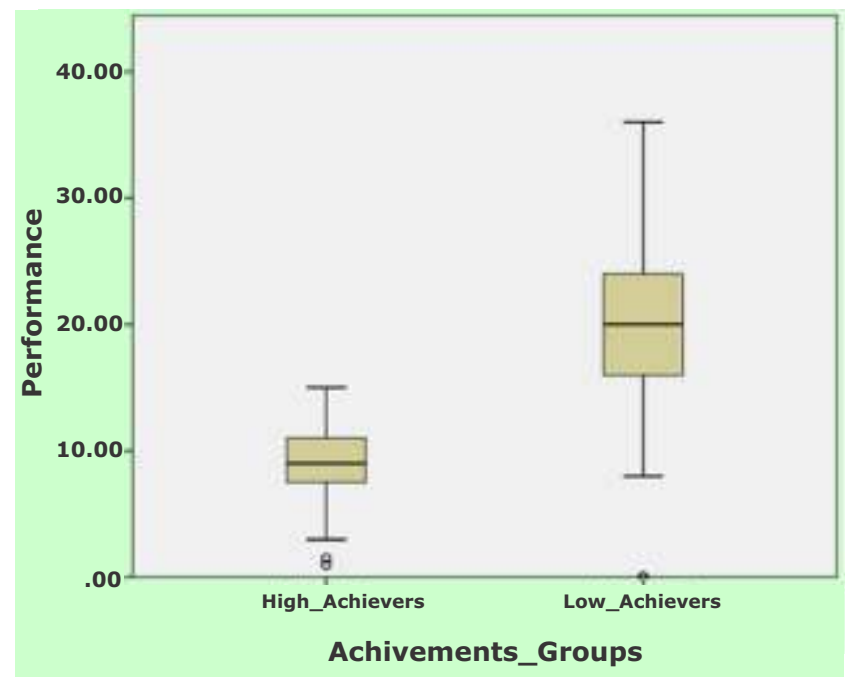

Figure-I: Combined whisker plot for high \& low achievers in online teaching. less motivated $21(30.4 \%)$ and grasping of difficult concepts was tough $48(69.5 \%)$. Although students agreed that teachers seemed more enthusiastic and cooperative in their online teaching $52(75.4 \%)$, but there was variety of teaching tools used in classroom 65 (94.2\%) vs online teaching 31 (44.9\%). Students agreed that online classes did promote self-regulated learning 50 (72.4\%). The frequency distribution of responses of students from both the groups is shown in the (figure-II).

Table-II showed that $52.2 \%$ of sample population is in the favor of class room teaching is more attractive, while $59.4 \%$ disagree online learning attractiveness, $2.9 \%$ of sample population strongly agree on online teaching, Chi-square test was applied and p-value 0.144 was calculated which is not significant. 


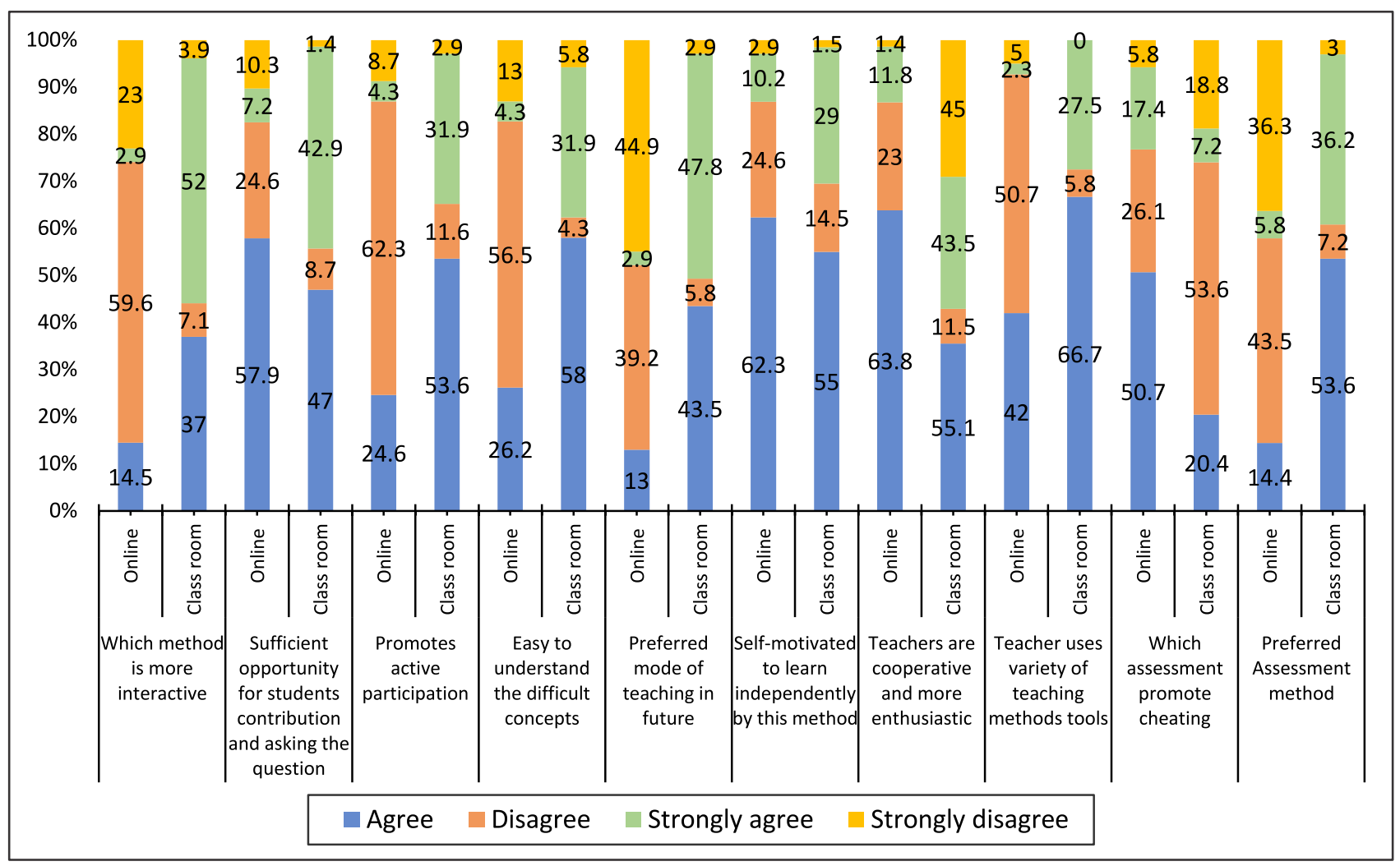

Figure-II: Comparison of Online Teaching vs Class Room Teaching.

Table-II: Comparison of Online vs Class room teaching more interactive.

\begin{tabular}{|c|c|c|c|c|}
\hline & \multicolumn{2}{|c|}{ Online Teaching } & \multicolumn{2}{|c|}{ Class room Teaching } \\
\hline & Frequency & Percent & Frequency & Percent \\
\hline Agree & 10 & 14.5 & 26 & 37.7 \\
\hline Disagree & 41 & 59.4 & 5 & 7.2 \\
\hline Strongly Agree & 2 & 2.9 & 36 & 52.2 \\
\hline Strongly Disagree & 16 & 23.2 & 2 & 2.9 \\
\hline Total & 69 & 100 & 69 & 100 \\
\hline \multicolumn{5}{|c|}{ Chi-Square Tests } \\
\hline & Value & df & \multicolumn{2}{|c|}{$\begin{array}{c}\text { Asymptotic Significance (2- } \\
\text { sided) }\end{array}$} \\
\hline Pearson Chi-Square & $17.150^{a}$ & 12 & \multicolumn{2}{|c|}{0.144} \\
\hline Likelihood Ratio & 18.160 & 12 & \multicolumn{2}{|c|}{0.111} \\
\hline $\mathrm{N}$ of Valid Cases & 69 & & & \\
\hline
\end{tabular}




\section{DISCUSSION:}

So far this has been one of the first studies to compare the classroom vs online teaching of a basic medical module in a Pakistani dental college during this challenging time of COVID19 pandemic. Riphah International University has been using Moodle (the Modular ObjectOriented Dynamic Learning Environment since 2005 which is one of the most user-friendly and verified open-source LMS. License of MS Teams was purchased and training of faculty immediately started regarding conducting of online classes and further training on updated version of Moodle with the help of IT team.

In our study, regarding the learning outcomes, students performed better in online assessments as compared to classroom assessments whereas the qualitative data suggested that majority of students preferred the classroom teaching while interacting face to face in a classroom environment that boost their motivation and in future would like to continue with the classroom teaching and assessment as compared to online teaching. A qualitative study on an ECG course at the University of UIm (2017) had the same experience by students where they preferred the face to face interaction with teacher vs the online course. This led them to conclude, to adopt strategies to enhance students internal and external motivation ${ }^{[10]}$. Similar perception was seen by Saudi students in an online questionnaire where they preferred the on ground more than the online education due to quality and accreditation ${ }^{[11]}$.

A study in Peking University of China during this COVID-19 pandemic interpreted through students' responses that for such a large scale online teaching, technical operational obstacles are not the main challenges for students. Instead, lack of a good learning attitude and cultural believes are hindering students learning and motivation. Students experience problems such as non-disciplined lifestyle and lack of individual space/good learning environments when they are self isolated at home ${ }^{[12]}$. This factor may have a role in our case too. Hence with the technical expertise and faculty training programs we need to keep in mind this contextual sociocultural aspect of our students as well. Contrary to our qualitative results another similar study conducted in Najran University-College of Nursing showed that e-learning group expressed higher satisfaction as compared to traditional group and final exams result showed a statistically significant improvement in the e-learning group $^{[13]}$.

Our results regarding the learning outcomes can be interpreted in two ways; viewing the students' feedback, cheating \& malpractices were common in the online format which could be a reason for better performance seen in the online assessment in both Biochemistry and Physiology as is agreed upon by majority of the faculty ${ }^{[14]}$. Although we used preventive techniques like one attempt allowed, randomizing questions, reshuffling of options, limited time given to minimize the digital cheating, still MCQs are considered the easiest online format for cheating with lack of online proctoring, hence we are now moving towards a balanced assessment strategy by adding open book exam to promote deeper learning of higher level learning outcome, in the medium stake assessments ${ }^{[15]}$. Higher Education Commission has also preferred the open book exam as the preferred mode of assessment in the online format as the mcqs alone might not be very successful in assessing the higher cognitive skills ${ }^{[16]}$. This is particularly important for medical/dental students where we want them to acquire problem solving, analytical skills in their professional life. Contrary to our results majority of the studies related to digital vs face to face learning have shown no statistically significant difference in both the modalities regarding learning outcomes ${ }^{[17-18]}$. The second interpretation could be that since the students were very anxious regarding the first online modular assessment they worked really hard to go through it or the test was made relatively easy to facilitate the students and ameliorate the additional COVID-19 lockdown related anxiety.

In ideal circumstances a blend of both strategies would benefit the students in meeting their diverse learning needs and will prepare to excel globally in this modern era of digitalization. Majority of undergraduate students have shown an inclination towards supplemental online learning rather a replacement for traditional teaching ${ }^{[19-22]}$. It is 
the need of hour to equip ourselves and tune our students to e-learning and COVID-19 pandemic has provided this opportunity as a silver lining through clouds.

\section{CONCLUSION:}

It was concluded that low performing students performed better as compared high performing students in case of online assessment. Majority students preferred online teaching, showed higher level of participation and promotion of self-study. However less interaction between fellow students and teachers as compared to class room teaching.

\section{ACKNOWLEDGEMENT:}

We offer sincere thanks to administration Islamic International Dental College.

CONFLICT OF INTEREST: All authors disclose no conflict of interest.

\section{GRANT SUPPORT \& FINANCIAL DISCLOSURE: None.}

\section{REFERENCES:}

1. Liyanagunawardena TR, Williams SA. Massive open online courses on health and medicine. Journal of medical Internet research. 2014;16(8):e191. Doi: 10.2196/jmir.3439

2. Sethi BA, Sethi A, Ali S, Aamir HS. Impact of Coronavirus disease (COVID-19) pandemic on health professionals. Pakistan Journal of Medical Sciences. 2020;36(COVID19-S4). Doi.10.12669/pjms. 36.COVID19-S4.2779

3. Gearhart D. Lack of Ethics for eLearning: Two Sides of the Ethical Coin. International Journal of Techno ethics (IJT). 2012;3(4):33-40. doi:10.4018/jte. 2012100103

4. Raji B. Significance and challenges of computer assisted education programs in the UAE: A case study of higher learning and vocational education. Education and Information Technologies. 2019;24(1):
153-164. Doi:10.1007/s10639-018-9767-6

5. O'Doherty D, Dromey M, Lougheed J, Hannigan A, Last J, McGrath D. Barriers and solutions to online learning in medical education-an integrative review. BMC medical education. 2018;18(1):130. Doi:10.1186/s12909-018-1240-0

6. Kintu MJ, Zhu C. Student Characteristics and Learning Outcomes in a Blended Learning Environment Intervention in a Ugandan University. Electronic Journal of e-Learning. 2016;14(3):181-195.

7. Taha MH, Abdalla ME, Wadi M, Khalafalla H. Curriculum delivery in Medical Education during an emergency: A guide based on the responses to the COVID-19 pandemic. Medical Education Publish. 2020: 16(1); 914. Doi:10.15694/mep.2020.000069.1

8. Hameed N, Hameed F. Effect of Cultural Factors on Students of Pakistan. International journal of education and information technologies. 2012: 6(4); 310-318.

9. Toprak E, Ozkanal B, Aydin S, Kaya S. Ethics in E-Learning. Turkish Online Journal of Educational Technology-TOJET. 2010;9(2):78-86.

10. Keis O, Grab C, Schneider A, Öchsner W. Online or face-to-face instruction? A qualitative study on the electrocardiogram course at the University of UIm to examine why students choose a particular format. BMC Medical Education. 2017;17(1):194. Doi:10.1186/s12909-017-1053-6

11. Alashwal M. The Experience of Saudi Students with Online Learning in US Universities. Higher Education Research. 2020;5(1):31-36. Doi: 10.11648/j.her. 20200501.16

12. Bao W. COVID-19 and online teaching in higher education: A case study of Peking University. Human Behavior and Emerging Technologies. 2020;2(2):113-115.

13. Amry AB. The impact of WhatsApp mobile social learning on the achievement and attitudes of female students compared with face to face learning in the classroom. European Scientific Journal.2014;10(22). 
Doi:10.19044/esj.2014.v10n22p\%p

14. Rogers CF. Faculty perceptions about echeating during online testing. Journal of Computing Sciences in Colleges. 2006; 22(2): 206-212.

15. Teodorczuk A, Fraser J, Rogers GD. Open book exams: A potential solution to the "full curriculum"? . Medical teacher. 2018;40(5):529-530. Doi:10.1080/ 0142159X.2017.1412412

16. Boitshwarelo B, Reedy AK, Billany T. Envisioning the use of online tests in assessing twenty-first century learning: a literature review. Journal Research and Practice in Technology Enhanced Learning. 2017; 12(1):16. Doi:10.1186/s41039017-0055-7

17. Harwood KJ, McDonald PL, Butler JT, Drago $\mathrm{D}$, Schlumpf KS. Comparing student outcomes in traditional vs intensive, online graduate programs in health professional education. BMC Medical Education. 2018;18(1):240. Doi:10.1186/s12909018-1343-7

18. Bowers J, Kumar P. Students' perceptions of teaching and social presence: A comparative analysis of face-to-face and online learning environments. International Journal of Web-Based Learning and Teaching Technologies. 2015; 10(1):27-44.

19. Asiry MA. Dental students' perceptions of an online learning. The Saudi dental journal. 2017;29(4):167-170.
20. Davis J, Chryssafidou E, Zamora J, Davies D, Khan K, Coomarasamy A. Computerbased teaching is as good as face to face lecture-based teaching of evidence-based medicine: a randomized controlled trial. BMC Medical Education. 2007; 7(1): 23-30.

21. Ary EJ, Brune CW. A comparison of student learning outcomes in traditional and online personal finance courses. MERLOT Journal of Online Learning and Teaching. 2011;7(4):465-474.

22. Paul J, Jefferson F. A Comparative Analysis of Student Performance in an Online vs. Face-to-Face Environmental Science Course From 2009 to 2016. Frontiers Computer Science. 2019;1:7-10. Doi: 10.3389/fcomp.2019.00007.

\section{Author's Contribution}

Fouzia Hanif: Study design, manuscript writing \& proof reading.

Fatima Ehsan: Over all supervision of data collection, analysis and manuscript writing.

Nasim Ilyas: Help in data collection \& final draft of study.

Safia S.Khan: Data analysis \& manuscript writing.

Submitted for publication: 08.09.2020

Accepted for publication: 13.11 .2020

After Revision 